\title{
E-recruitment Technology Adoption among Generation Z Job-Seekers
}

\author{
Neeta Jayabalan, Zafir Khan Mohamed Makhbul, Jenny Marisa Lim Dao Siang, Nor Azim Bin \\ Hj Ahmad Radzi, Muhammad Ashraf Bin Anuar.
}

\begin{abstract}
In line with the technological changes in the industry revolutionary era of the 4.0, today's organizations have also quickly adopted new or digital technology trends. One of these new trends is E-recruitment in human resource management. Online recruitment is also known as E-recruitment which is a HR software that uses technology in a particular web-based to guide and assist the hiring process in order to reduce the financial burden, improve the effectiveness of administrative and gain access to a wider pool of talent. A total of 230 data were collected from the $Z$ generation respondents selected purposively convenience. The data was analyzed using the PLS structure equation model to identify the adoption of E-recruitment technology by generation $Z$. The results of the multi-level analysis showed that the expectation of positive results affects E-recruitment retrieval. Findings and suggestions provide valuable insights on E-recruitment and its implications in the modern era of revolutionary industry 4.0.
\end{abstract}

Keywords- E-recruitment; Technology Readiness Index; optimistic; discomfort; insecurity; innovativeness.

\section{INTRODUCTION}

Recruitment is one of the important responsibilities and task in a HR department. Recruitment is the process of finding and hiring best-qualified candidates which can benefit most of the company [1]. However, the recruitment process had been influenced by technology which is known as E-recruitment. According to [2] E-recruitment is also known as online recruitment which is a HR software that uses technology in a particular web-based to guide and assist the hiring process in order to reduce the financial burden, improve the effectiveness of administrative and gain access to a wider pool of talent. E-recruitment had been centred on major job sites and social media in order to reach the potential candidates faster. Although e-recruitment had bring many benefit to the human resource management field but it

Revised Manuscript Received on December 30, 2019.

* Correspondence Author

* Neeta Jayabalan, Faculty of Business, Accountancy and Management, SEGi University, Petaling Jaya, Selangor, Malaysia.

Zafir Khan Mohamed Makhbul, Faculty of Economics and Business, Universiti Kebangsaan Malaysia, UKM Bangi, Selangor, Malaysia.

Jenny Marisa Lim Dao Siang, Faculty of Business and Finance, University Tunku Abdul Rahman, Kampar, Perak, Malaysia

Nor Azim Ahmad Radzi, Faculty of Business and Finance, University Tunku Abdul Rahman, Kampar, Perak, Malaysia

Muhammad Ashraf Bin Anuar, Faculty of Business and Finance, University Tunku Abdul Rahman, Kampar, Perak, Malaysia

(C) The Authors. Published by Blue Eyes Intelligence Engineering and Sciences Publication (BEIESP). This is an open access article under the CC BY-NC-ND license (http://creativecommons.org/licenses/by-nc-nd/4.0/) also bring along the disadvantages of it [3]. For example, a longer period of time is spend in sorting surplus and unsuitable candidates.

Besides, higher percentage of hiring imperfect candidate to job match might also increase the rate of resignation. Therefore, it is important for us to further know and learn about e-recruitment and find the solution for problem it brings.

E-recruitment means that a company is using a new technology or the Web-based resources to recruit employees such as interviewing, finding, attracting candidates, screening applicants, and assessing candidates. In globalization, e-recruitment is one of the technology that is growing rapidly in the human resource management field. E-recruitment uses the internet to post and advertise vacancies. Communication can take place via email between employers and candidates to get the information about the organization and the jobs [4]. Moreover, Job seekers have more opportunity in finding the suitable jobs through the social networking sites such as Facebook, Google, and LinkedIn. E-recruitment allows the candidates to do an online testing for evaluating their different factors based on their different job profiles.

Globally, generation $\mathrm{Z}$ already join the workforce and now they going to be the major job seekers elsewhere. Generation Z is the generation born in the span of 1995 until 2010. Generation $Y$ is before Generation $Z$, this generation is a Generation Y transition with increasingly developing technology [5]. According to Business today (2019) [6], 71 percent of digital generation thinks they are digitally proficient, but 97 percent worry that they lack the necessary soft skills. Digital era generation is also eager to shape the world of work in the future by leading and helping others, but argues that human interaction remains an important component in the workplace.

Although the generation has begun interacting with electronic devices since birth and growing up with social media, they still expect interaction among people at work. A total of eight out of 10 (81 percent of respondents) expect to learn from colleagues or others, not online, while 74 percent choose to talk face-to-face rather than text-based communication through technology. In addition, 55 percent chose to work in the office instead of working from home and 66 percent wanted to work in groups rather than alone [6]. Dell Technologist's study involves 4,300 Generation Z from Southeast Asia, including Indonesia, the Philippines, Singapore, Thailand, Vietnam and 724 respondents from Malaysia also shows 90 percent of Generation Z have a profound interest in technology-related careers [6].

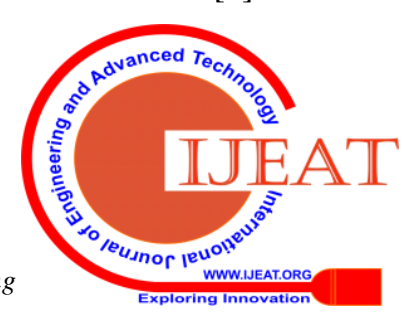


As many as 41 percent of Malaysian generation $\mathrm{Z}$ are interested in information technology care, 44 percent cyber security and 54 percent technology and development research, while 98 percent of generation $Z$ have used technology as part of formal education and 94 percent argue that technology offered by employers is the reason of them choosing the job offered [6].

Furthermore, e-recruitment has effectively increase the efficiency of the recruitment method which is one of the benefit provided to the HR manager in managing the process. Online recruitment is also known as E-recruitment, has many advantages to organization such as better match, low in cost, quick, less time, and wider area [7]. Other than that, E-recruitment will automatically store the data of the job opening for the recruitment management purpose and save the cost for all the hard copies of advertising job offers [4]. Moreover, e-recruitment can automatically delete all the unsuitable candidates and efficiently provide feedback to candidates who are unqualified. Other than that, e-recruitment also provides benefits to job seekers. In the modern generations, people like to use online applications rather than the traditional applications, because it can save money, time, and able to find more different scope of job offers, and post their resume through the e-mail [5]. Therefore, e-recruitment help the work of human resources management and job seekers become more convenient.

Besides, by using e-recruitment might face different challenges in the human resources management field. The current challenges is technology revolution towards artificial intelligence which the company need to pay the high star-up costs, maintenance costs and updating costs, in all industries. This is especially true for IT since their investment and financial possibilities are significantly more limited than those of larger companies [8].

Therefore, e-recruitment is not only a strategic decision, it is also a problem of financial capacity face by the IT industry. In addition, data security and confidentiality problem is also a challenge because many applicants will fear that their personal detail are not safe. Meanwhile, company will return the resume to the candidates if they are unqualified through the traditional method but e-recruitment enables the resume to stock in the database and the information can be traced back.

However, job seekers will also face some challenges if they have limited access to internet when using the online recruitment to find and apply for job vacancies, especially the individuals from certain regions of the world and the lower social-economic groups. Therefore, when using e-recruitment system, challenges may occur to the human resources management towards Industrial revolution 4.0 [9]. In this case IT companies Human resource department need to find out the technology readiness towards industrial revolution 4.0 on e-recruitment among generation $\mathrm{Z}$. The purpose of the research to improve the behaviour intention of generation $\mathrm{Z}$ to use E-recruitment

\section{LITERATURE REVIEW}

According to [10] and [11], willingness of people to adapt and embrace new technologies in achieving their goals in the organization is also known as Technology Readiness (TR). TR is used to identify the predisposition of a person in use of the new technologies. Technology Readiness Index (TRI) is establish to measure individual trust on technologies. TRI has four sub area which are optimism, innovativeness, insecurity, as well as discomfort [12]. Innovativeness and optimism are the mechanism of TR or to be said as positive beliefs about technology. However, insecurity and discomfort are hindrance and has a negative thoughts on technology.

In this study, the dependent variable and independent variables are being chosen after the studying done for literature review. The four dimension innovativeness, optimism, insecurity, as well as discomfort are independent variables and intention to use e-recruitment technology is dependent variable that are adopted from research conducted by [10] and [11].

\section{RESEARCH FRAMEWORK}

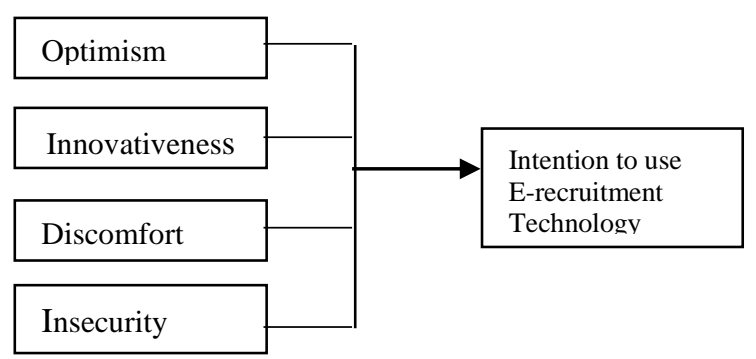

Figure 1

\section{HYPOTHESIS DEVELOPMENT}

\section{A. Relationship between Optimism and Intention to use E-recruitment Technology}

Optimism was seen as the positive attitudes towards the intention to use new technology. It reflects a positive image on technology and trust technology will help people to increase flexibility, control, and efficiency [10], [11]. This shown that before new technology introduces, optimists have a positive effects on technology. In order to achieve the anticipated result, optimists will use effective optimistic strategies. [13] and [14], said that optimists having positive attitude which help in fostering more positive attitudes towards new technology. The openness of optimists makes them less likely to be escapists and more probable to accept their condition. As a result, optimists are willing and more prepared to use new technologies.

Technology optimists have self-confidence on the ability of mastering new technology makes them have an innate positive perception on new technologies. Optimism direct a positive behaviours and attitudes towards the use of new technology [15]. Therefore, optimists are categories as willing to adapt new technologies [16]; [17]. From past studied done by [18], found out that individuals with high optimism will have high acceptance on self-service technology. We can state that the optimists have the intention to use new technology as they accept new technology is functional, useful and convenient because they worry less on negative results or outcomes.

H0: There is no positive relationship between optimism and intention to use E recruitment among generation $\mathrm{Z}$

H1: There is a positive relationship between optimism and intention to use E recruitment among generation $Z$ 


\section{B. Relationship between Innovativeness and Intention to use E-recruitment Technology}

Generally, innovativeness has make technology as a pioneer [19]. [20] defined innovativeness as individual willingness in exploring new technology that newly release into the market. Moreover, innovative person is always ready for the new technology and willing to try them base on professional knowledge.

High technology innovative individuals will have strong motivation and drives to try and use new technology as they enjoy and energize with new technologies stimulation. Highly innovative people are not really bothered about whether uses of technology are easy or not compared with less-innovative people. Highly innovative individuals may intend to experience challenging difficulties in using new technology [21]. Moreover, highly innovative people has less-complex trust on new technologies [22]. This means that they will not view new technology as hard or complex to understand. Therefore, highly innovative individuals will have more intention to use new technologies than those less innovative individuals.

HO: There is no positive relationship between innovativeness and intention to use E recruitment among generation $Z$

H1: There is a positive relationship between innovativeness and intention to use E recruitment among generation $Z$

\section{Relationship between Discomfort and Intention to use E-recruitment Technology}

Discomfort is a feeling of confusion and lack of control on technology [10], [11]. Discomfort on technology will affect individuals to believe that the technology is controlling them. Moreover, people will feel more complicate and uncertain about new things if they are having a low comfort and uncertainty on adopting new technologies [23].

Therefore, people who are uncomfortable with technology should adopt easier technology in order to attain a similar intention level to use new technology long with individual that have high comfort level. Likewise, to obtain the exact intentions of behaviour, these people must trust that new technology adoption will bring them greater benefits compare to those with a high comfort level [24].

According to [25] and [26], they found that uncomfortable on technology face by a person will cause them hardly to adopt technology because they cannot control the technology and feel anxiety about being control by the technology. Therefore, it can be seen that people who are highly uncomfortable to technology will perceive the new technology as a threat and eventually affect their intention to use the technology.

H0: There is no negative relationship between discomfort and intention to use E recruitment among generation $Z$

H1: There is a negative relationship between discomfort and intention to use E recruitment among generation $\mathrm{Z}$

\section{Relationship between Insecurity and Intention to use E-recruitment Technology}

Security issue is the most concern by those people who want to use new technology, especially for financial transaction systems. Insecurity always refers to the feeling of lack of trust of technology, doubtfulness on the system and its capacity to function appropriately, and worry about its possible threat and harmfulness [11]. Perception of insecurity will be the barrier to adoption of new technology [27]. The studies of [28] and [29] reported that insecurity affects people attitudes negatively. The innate fear might be the reason why individuals avoiding technologies. Scepticisms of people towards new technologies may be the reason of their innate fear [30].

As stated by [10] and [11] individuals with high insecurity score will always feel unconfident on the new technology security, they certainly requires assurances to ensure it's safe and secure. They will only take the risks in adapting new technology if it brings a great benefit to them. [31] studies on consumers' behaviour towards online store also shows that individual's intention to do purchasing through network is affected by the security level on network. Therefore, we can argue that insecurity of an individual will affect their intention to use new technology.

HO: There is no negative relationship between insecurity and intention to use E recruitment among generation $Z$

H1: There is a negative relationship between insecurity and intention to use E recruitment among generation $Z$

\section{METHODOLOGY}

According to [32] research set out is a composed, precise, information-based, critical, objective, scientific inquiry or analysis into a particular issue embraced to find answers or answers for it. The creator likewise expressed that research incorporates the procedures of inquiry, examination, assessment, and experimentation. These procedures must be done deliberately, diligently, critically, objectively, and logically. [33] characterized a research methodology as the methodology in which the research purposes can be addressed. Fundamentally, there are two sorts of research techniques. These two kinds are known as 'quantitative research' and 'qualitative research [33], [34]. As expressed by [33], the fittingness of the sort use is dependent on the nature and motivation behind the examination.

This examination was embraced all through the peninsular of Malaysia focused on age $\mathrm{Z}$ as our objective populace. The survey was directed in Jun 2019, with objective respondents of 200 respondents determined by $G$ power with minimum 90 samples, demonstrated after [35]. The nonprobability testing using comfort examining strategy was utilized [36].

The items in the self-administered survey were embraced from the past researcher according to table 1 on the TRI. The questionnaire comprised of three areas: statistic profiles, TRI and appropriation. During the procedure of information accumulation, researcher colleagues gave a short preparation to the respondents before they addressed the questionnaire. Information gathered had been breaking down utilizing Statistical Package for Social Science (SPSS 25.0) and PLS-SEM version 3.2.8. Cronbach's Alpha had been utilized to measure the reliability [32].

\section{RESULTS ANALYSIS}

To begin with, the measurement models of the sum total has been analysed for reliability, before testing speculative models, discrimination validity and convergence validity were tested.

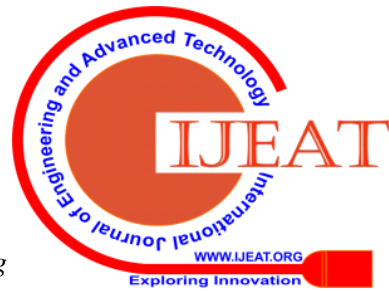


Table 3 shows the scores of measurement model and all heaps are higher than 0.70 which is the threshold proposed by [37]. The (AVE) average variance extracted of the agreements surpasses 0.5 [38] while (CR) composite reliability score indicate higher than 0.7 [37]. In this way, we can infer that Convergent ends are accomplished.

The analysation of VIF (Table 3 ) to test for potential issues of multicollinearity had identified a scope of underneath 3.3 of the VIF esteems for every one develops affirms adequate build validity by an absence of multicollinearity. This is additionally on the grounds that the qualities fall fundamentally underneath the base threshold of 9 [39].

Table 4 demonstrates that outcomes for the validity trial of discrimination. As Suggested by [40] and [41], AVE for all improvement ought to be in higher correlation among them and whatever else development model. As appeared in Table 5, all developments meet this model demonstrating development has the validity of discrimination. [37] demonstrates that the measured variable loading of items ought to be higher compare to cross-load by all at any rate 0.1 to show the legitimateness of discrimination adequate. As appeared in Table 5 contains all developments meeting this foundation. Therefore, we can presume that the validity of discrimination is accomplished.

[42] Additionally proceeded to exhibit the unrivalled performance of this strategy by means of a Monte Carlo reproduction study. All things considered, we have likewise tried the discriminant validity utilizing this new proposed strategy and the outcomes appeared in Table 4. There are two different ways of utilizing the HTMT to evaluate discriminant validity: 1 as a measure or 2 as a statistical test. For the first, if the HTMT worth is more noteworthy than HTMT.85 estimation of 0.85 [43], or HTMT.90 estimation of 0.90 [44] at that point there is an issue of discriminant validity.

Table 1 Convergent validity

\begin{tabular}{lcccc}
\hline Constructs & Loadings & CR & AVE & VIF \\
\hline Discomfort1 & 0.708 & 0.872 & 0.577 & 1.493 \\
Discomfort2 & 0.794 & & & 1.747 \\
Discomfort3 & 0.742 & & & 1.58 \\
Discomfort4 & 0.709 & & & 1.466 \\
Discomfort5 & 0.838 & & & 2.058 \\
Innovativeness1 & 0.805 & 0.883 & 0.653 & 1.795 \\
Innovativeness2 & 0.791 & & & 1.627 \\
Innovativeness3 & 0.836 & & & 1.762 \\
Innovativeness5 & 0.8 & & & 1.783 \\
Insecurity1 & 0.712 & 0.901 & 0.602 & 1.594 \\
Insecurity2 & 0.745 & & & 1.698 \\
Insecurity3 & 0.78 & & & 1.93 \\
Insecurity4 & 0.785 & & & 1.91 \\
Insecurity5 & 0.813 & & & 2.31 \\
Insecurity6 & 0.814 & & & 2.362 \\
Intention to use 1 & 0.866 & 0.923 & 0.8 & 2.14 \\
Intention to use 2 & 0.913 & & & 2.656 \\
Intention to use 3 & 0.905 & & & 2.458 \\
Optimism1 & 0.797 & 0.895 & 0.631 & 1.773 \\
Optimism2 & 0.817 & & & 1.994 \\
Optimism3 & 0.752 & & & 1.646 \\
Optimism4 & 0.768 & & & 1.844 \\
Optimism5 & 0.835 & & & 2.055 \\
\hline
\end{tabular}

Table 2 Fornell \& Lackers

\begin{tabular}{lccccc}
\hline & DIS & INN & INS & INT B & OPT \\
\hline DIS & $\mathbf{0 . 7 6}$ & & & & \\
INN & -0.508 & $\mathbf{0 . 8 0 8}$ & & & \\
INS & 0.709 & -0.503 & $\mathbf{0 . 7 7 6}$ & & \\
INT B & -0.759 & 0.616 & -0.786 & $\mathbf{0 . 8 9 5}$ & \\
OPT & -0.406 & 0.526 & -0.441 & 0.529 & $\mathbf{0 . 7 9 4}$ \\
\hline
\end{tabular}

Table 3 Cross Loadings

\begin{tabular}{lccccc}
\hline & DIS & INN & INS & INT B & OPT \\
\hline Discomfort1 & $\mathbf{0 . 7 0 8}$ & -0.312 & 0.406 & -0.498 & -0.166 \\
Discomfort2 & $\mathbf{0 . 7 9 4}$ & -0.484 & 0.601 & -0.619 & -0.371 \\
Discomfort3 & $\mathbf{0 . 7 4 2}$ & -0.307 & 0.528 & -0.57 & -0.349 \\
Discomfort4 & $\mathbf{0 . 7 0 9}$ & -0.45 & 0.473 & -0.528 & -0.31 \\
Discomfort5 & $\mathbf{0 . 8 3 8}$ & -0.374 & 0.654 & -0.652 & -0.325 \\
Innovativeness1 & -0.327 & $\mathbf{0 . 8 0 5}$ & -0.364 & 0.461 & 0.37 \\
Innovativeness2 & -0.44 & $\mathbf{0 . 7 9 1}$ & -0.433 & 0.494 & 0.375 \\
Innovativeness3 & -0.488 & $\mathbf{0 . 8 3 6}$ & -0.462 & 0.571 & 0.492 \\
Innovativeness5 & -0.369 & $\mathbf{0 . 8}$ & -0.355 & 0.452 & 0.456 \\
Insecurity1 & 0.494 & -0.454 & $\mathbf{0 . 7 1 2}$ & -0.59 & -0.294 \\
Insecurity2 & 0.588 & -0.378 & $\mathbf{0 . 7 4 5}$ & -0.596 & -0.353 \\
Insecurity3 & 0.569 & -0.386 & $\mathbf{0 . 7 8}$ & -0.62 & -0.372 \\
Insecurity4 & 0.536 & -0.438 & $\mathbf{0 . 7 8 5}$ & -0.611 & -0.406 \\
Insecurity5 & 0.525 & -0.321 & $\mathbf{0 . 8 1 3}$ & -0.596 & -0.256 \\
Insecurity6 & 0.586 & -0.368 & $\mathbf{0 . 8 1 4}$ & -0.645 & -0.369 \\
Intention to use 1 & -0.604 & 0.516 & -0.605 & $\mathbf{0 . 8 6 6}$ & 0.463 \\
Intention to use 2 & -0.702 & 0.545 & -0.745 & $\mathbf{0 . 9 1 3}$ & 0.476 \\
Intention to use 3 & -0.721 & 0.59 & -0.748 & $\mathbf{0 . 9 0 5}$ & 0.481 \\
Optimism1 & -0.337 & 0.415 & -0.401 & 0.478 & $\mathbf{0 . 7 9 7}$ \\
Optimism2 & -0.327 & 0.409 & -0.311 & 0.411 & $\mathbf{0 . 8 1 7}$ \\
Optimism3 & -0.329 & 0.397 & -0.342 & 0.397 & $\mathbf{0 . 7 5 2}$ \\
Optimism4 & -0.255 & 0.348 & -0.261 & 0.325 & $\mathbf{0 . 7 6 8}$ \\
Optimism5 & -0.347 & 0.501 & -0.408 & 0.461 & $\mathbf{0 . 8 3 5}$ \\
\hline & & & & \\
\hline
\end{tabular}

Table 4 HTMT

\begin{tabular}{cccccc}
\hline & DIS & INN & INS & INT B & OPT \\
\hline DIS & & & & \\
INN & 0.613 & & & \\
INS & 0.834 & 0.591 & & \\
INT B & 0.891 & 0.718 & 0.897 & \\
OPT & 0.476 & 0.617 & 0.503 & 0.603 \\
\hline
\end{tabular}




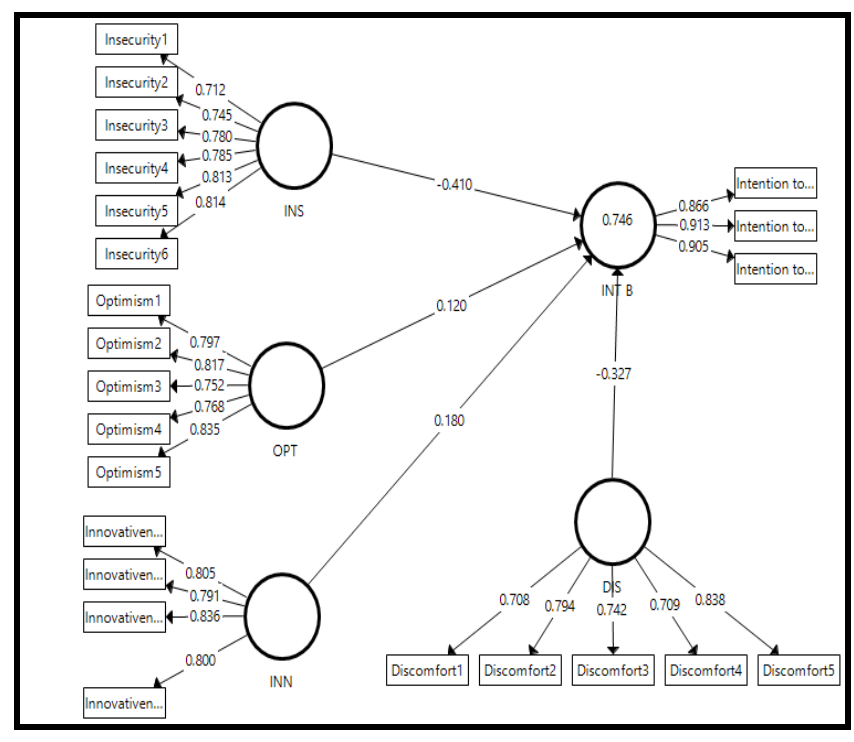

Fig. 2 Measurement Model

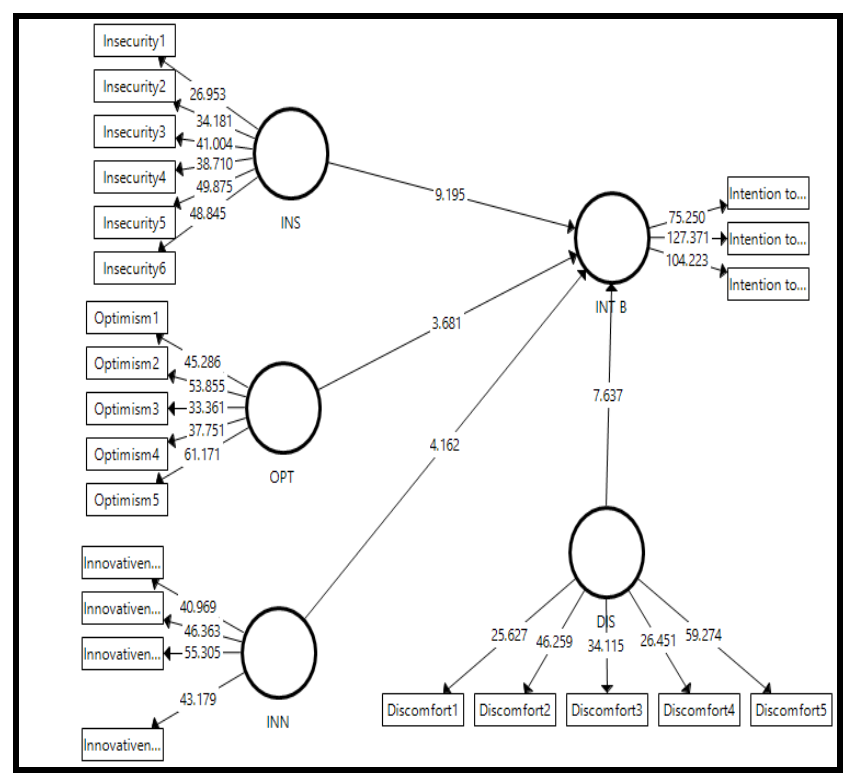

Table 5: Hypothesis results

\begin{tabular}{ccccl}
\hline Hypothesis & Beta value & T Value & P Values & Decision \\
\hline DIS -> INT B & -0.327 & 7.637 & 0 & Supported \\
INN -> INT B & 0.18 & 4.162 & 0 & Supported \\
INS -> INT B & -0.41 & 9.195 & 0 & Supported \\
OPT -> INT B & 0.12 & 3.681 & 0 & Supported \\
\hline
\end{tabular}

\section{DISCUSSION OF FINDINGS}

In this study, questionnaire was filled up by 230 respondents. Respondents were mostly from the age group of of 18 to 24 years, Race is others and undergraduate as education level. Reliability test resulted 0.843 under the pilot study, which demonstrates the questionnaire is perfect and dependable.

\section{A. Bootstrapping Results of Smart PLS 3.2.8}

The outcomes were obtain from 230 respondents and dissected using Smart PLS 3.2.8. To analyze the significance of statistical coefficients. [45] prescribe a base of confidence interval are measured based on 1.65 t-statistics values at $p \leq$
Fig. 3 Structural Model

0.1. Similarly, [46] embrace that effect sizes of large 0.35, medium 0.15, and small effects 0.02. [47] highlighted the values for R 2 are substantial 0.75 , moderate 0.50 , and weak 0.25 .

Determination of coefficient is identified in $\mathrm{R}$ Square under dependent constructs. As indicated by [48], he state that $\mathrm{R}$ square of 0.67 indicates as strong, 0.33 indicates of a moderate $\mathrm{R}$ square and 0.19 indicates as weak $\mathrm{R}$ square. While as per [49], the $\mathrm{R}$ square of 0.75 indicates as strong, 0.5 as moderate, and 0.25 as weak $\mathrm{R}$ square. [50] suggested that $\mathrm{R}$ square altogether ought to be equivalent or more than 0.10 , this clarified the variance to be specific and considered sufficient as endogenous construct.

To reach a significance level, 5000 subsamples were utilized in initiating bootstrapping PLS option [51]. Thus, in view of this researcher's study, the R square is strong (0.746). Researchers need to be familiar on F Square so as to think about the model intensity. To determining a decent model, researchers refer to the effect size (f square). Refer to the study, large effects were identified, taking everything into account, researchers realized the Inner Model measurement met the requirement of the Modal.

Table 5 indicates the list of $\mathrm{H} 1$ to $\mathrm{H} 4$ hypothesis. In addition for all the hypothesis T-statistics value were stated. At the point when the hypothesis is identified as significant if the t-value indicates more than 2.58 ( $\mathrm{p}<0.01$ ), or t-value indicates as more than $1.96(\mathrm{p}<0.05)$, or $\mathrm{t}$-value indicates more than $2.33(\mathrm{p}<0.01)$ for 1 -tail test or t-value indicates as more than $1.645(\mathrm{p}<0.05)$. From Table 5 specify four hypotheses, stated as H1, H2, H3 and H4. This hypotheses are significant from the fact that the positive value were shown from the lower limit and maximum limit. This shows the hypothesis had turned out to be significant which is zero.

\section{IMPLICATION OF THE STUDY}

\section{A.Optimism}

In this research is shows that there is a significant positive relationship between optimism and intention to use E-recruitment. According to [11] an organization can form a "customer advisory panels" with the function to provide recommendations into the issues regards to assign of servicing staff, the formulation of creative service design and the way to upgrade quality of service.

Recruitment organisation can also refer to this technique to form a "IT advisory panel" in order to upgrade the quality of service on the E-recruitment which in term lead to the increase of generation $Z$ ' willingness on using E-recruitment. The management can recruit fresh graduate to join into the development process of E-recruitment. After the recruitment they can started to apply TR scale on them to classify out who are the one with high score in optimism dimension. Afterwards, the management can retain those who are qualified and assists them to form a small responsible team. Thus, if any implementation problems occur, they are the one who will face the issues first. The $1^{\text {st }}$ hand information about the E-recruitment receive by them are far more accurate than the prediction that have been made by the implementation body.

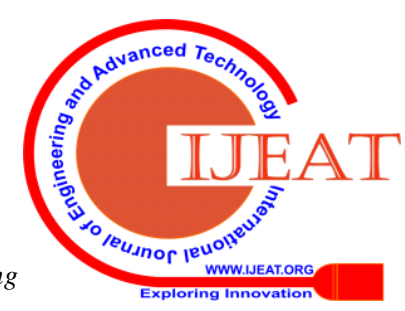


With a reliable information sources, the relevant department can figure out several strategies to precisely counter the problem occurs during the implementation of the E-recruitment system.

\section{B. Innovativeness}

The research shows that there is a positive significant relationship between innovativeness and intention to use E-recruitment among gen $\mathrm{Z}$. Innovativeness was the positive driver for people with the intention to use new technology [10], [11]. It was important because innovativeness brings positive impact towards intention to use technology. Student are the important element on evaluate the using of new recruitment system, so the innovativeness of individuals plays an important role in increasing the intention to use E-recruitment. In order to improve student's innovativeness for gen $\mathrm{Z}$, the management should always utilise this innovative system and communicates on the function and benefits they gains on this the new recruitment system. Business management can specifically assign certain officers to be the speaker regards to this E-recruitment system to educate the generation $\mathrm{Z}$ on this system. As the officers change their attitudes towards innovative product, it can be positively influence the diffusion and acceptance of technology among the generation $\mathrm{Z}$ [52].

\section{Discomfort}

Discomfort is a negative influence on intention to use the technology [10]. To increase the intention to use of generation $\mathrm{Z}$ toward E-recruitment, business organization can provide more information and explain the usage of E-recruitment for generation $\mathrm{Z}$. The information must be simple and easy to understand thus generation $\mathrm{Z}$ will not feel discomfort and this will also enhance knowledge of student about the usage of E-recruitment. The explanation must provide sufficient knowledge to generation $\mathrm{Z}$ regarding this advance technology, so generation $\mathrm{Z}$ will not feel unable to use the technology (E-recruitment). Therefore, there is a necessity for business organization to organise the talk regards to this E-recruitment system in order to enhance the understanding towards this system. In other words, instead of just giving the information in words on the papers, business organization should have some talk in each semester to educate the new comers as well as motivating the present generation $\mathrm{Z}$ to participate in this system.

\section{Insecurity}

The research shows that there is a negative relationship between insecurity and intention to use E-recruitment among generation $\mathrm{Z}$. In order to decrease the level of the feeling of insecurity among users, organization should organize a security awareness program to the organization staffs itself. It aim to ensure the staffs are aware the importance of protecting sensitive and private information of the users, the reason why they should handle the users personal information securely and the causes of mishandling information [53]. By doing so, this will also help to creates or raises the confidence level of the users. This is because when the business organization management implement this program, it directly shows that they are concern about the security issues faces by the users. recruitment officers also play pivotal roles. As the role model

In every organization, the feeling of insecurity to the new technology implication is the critical factors for peoples. Therefore, the organization should provide a high security system for the users in order to create a safe and secure environment when there are using the new technologies-based services. The data is importance as core of every business. If the organization inability to protect the user's personal data, it will be the end of the business [54].

\section{E. Limitation of the Study}

Throughout the complete research study conducted, encountered several critical limitations in the progress of the research that will undoubtedly bring tremendous influences to the research reliability and accuracy outcomes. The $1^{\text {st }}$ limitation that are going to be described is about the sample size that adopted in this study. To be honest, this study consists of limited sample size as from our finalise discussion. The insufficient of the sample sizes might have restricted our research team to seek for wider and more complete data range. This is because in this research study, the research team only emphasis on the majority users of the E-recruitment which are generation $\mathrm{Z}$ and forgone all the minority users for instance, the staffs in business organization. Thus, there may be a possibility that the sample size which we have applied do not precisely signifies and represents all the users of E-recruitment.

The $2^{\text {nd }}$ limitations of our research study will be fall on the survey questionnaires and its process. This situation occurs because the questions that the team use in the survey questionnaire are not fully designed by their own. Most of the questions are adopted from the past researchers' questionnaires which have been proven to be relevant to this research topic. Thus, the real meanings between what the research team intends to ask may be slightly different from the applied questions in certain extents. Although the variance between the actual implications is insignificant, but the team do not have any direct evidence to guarantee that this dissimilarity will not poses any influences on the final outcomes.

The $3^{\text {rd }}$ limitation that the team discover that few of the respondents do not answer the question seriously. Hence, the researchers have the difficulties to obtain the reliable information which are more relevant to this topic. Therefore, critical bias and error will have high tendency to occur, meanwhile, it might drastically effect the preciseness and reliability of finalise outcomes. As the result, the data that the team collected from the target respondents might not support a strong relationship between the dependent and independent variables

\section{F. Recommendations for future study}

In this research, there are numerous of limitations the team have encountered. These weaknesses have been specifically mentioned and explained on above section. First of all, the expansion on the sample size of this research is necessary. This is because the as the sample sizes increases, the tendency to receive more precise results will also be greatly improved. Based on this statement, the research team should enlarge the research coverage areas. 
This means that the researchers should increase the amount of the target respondents who involve in this research study. In other words, it also illustrates that the research team should not solely emphasis on the majority users of E-recruitment which are the generation $\mathrm{Z}$ only. All the minority users must also be included although this small population may not exert significance effect on the final results. By doing so, the accuracy and reliability of the research will definitely be enhanced as well as avoid critical bias and error to happen. Lastly, the team can also guarantee that the sample size which users of E-recruitment.

The $2^{\text {nd }}$ recommendations will mostly base on the improvement of the questionnaires and the process. To design their own questionnaires manually in this study rather than adopt the past researchers' questionnaires. This is because there are no other exactly same questionnaires regard to this topic. The past researchers' questionnaires can be the foundation for the team to build up their own unique questionnaires which in another meaning, the past researchers' questionnaires should only act as the references for the formulation of questionnaires. In this way, questions which are indirect and ambiguous in term of its meaning can be avoided.

The $3^{\text {rd }}$ recommendation is that the future researchers can perform the online survey method to gather the result from all the target respondents in business organization. This medium will bring conveniences to both the researchers and the respondents. On the side of the team, they can save plenty of the cost and time that needed to collect back the questionnaires while for the respondents, they will have enough time to read and understand the questions without being rush to submit the questionnaires in a short notice of time. Therefore, the results that achieved in this kind of circumstances will more likely to be precise and reliable as compare to previous situation. Moreover, the researchers also need to conduct a short conversation with the target respondents first before giving them the questionnaires. The purpose of this short conversation is to communicate the affairs about the E-recruitment especially on its actual and multiple functions.

Last but not least, the $4^{\text {th }}$ recommendation is that the future researchers can also try to emphasis on other related element since this research study is mainly focus on the 4 dimension in the technology readiness only which are optimism, innovativeness, discomfort and insecurity. This can be proven by the result of $\mathrm{R}^{2}$ in the Multiple Regression Analysis. Through the results, it is crystal clear that the existence of other related factors that will exert influences on the dependant variable are undoubtedly. In this research, the secondary database which act as another source of resources also plays a pivotal role for the team to receive the information wanted in this study. Thus, business organization must always keep up-to-date regards the resources in their secondary database to support the researchers in obtaining valuable information

\section{CONCLUSION}

In the nut shell, the research team really have gained a better and comprehensive understandings regards to the factors that influence the intention to use E-recruitment have applied will precisely signifies and represents all the

among generation. Based on what we have acquired from the study, we discover that the four independent variables which are optimism, innovativeness, insecurity and discomfort really exert tremendous effect on the intention to use. We prove that both innovativeness and optimism are the drivers that will increase overall technology readiness which in term lead to more intention to use the new technology.

At the same time, we also know that the insecurity and discomfort will always act as the inhibitors that reduce the technology readiness which causes drastically reduce in the intention to use advanced technology. Both of the drivers will exert influences among themselves, meanwhile, also will affect the both of the inhibitors. In other words, the effect will not just stop in inter group whereas it will also carry on between the intra group. The drivers as usual, affect positively the technology readiness and intention to use while the inhibitors will negatively affect the technology readiness and also the intention to use.

From the result in this topic, it is sufficient to conclude that the strongest influential factor that positively affect the intention to use E-recruitment will be the innovativeness accompany by the optimism factors that also reaches the second most influential factor towards the willingness to use E-recruitment. Both of the drivers are crucial in increasing the rate of respondents to use E-recruitment. The more the drivers available in area of the research, the higher the technology readiness it will be. This in term will result in the increases of intention to use E- recruitment technology.

\section{REFERENCES}

1. Sarker, S., Xiao, X., Beaulieu, Tanya., Lee, A. S. (2018). Learning from First-Generation Qualitative Approaches in the IS Discipline: An Evolutionary View and Some Implications for Authors and Evaluators (PART 2/2). Journal of the Association for Information Systems, 909-923. doi:10.17705/1jais.00512

2. Ekanayaka E.M.M.S., \& Gamage P., (2019) Factors Influencing Job Seeker's Intention to Use E-Recruitment: Evidence from a State University in Sri Lanka. International Journal of Managerial Studies and Research (IJMSR) Volume 7, Issue 8, August 2019, PP 1-12

3. Melanthiou, Y., Pavlou, F., \& Constantinou, E. (2015). The Use of Social Network Sites as an E-Recruitment Tool. Journal of Transnational Management, 20(1), 31-49. doi:10.1080/15475778.2015.998141

4. Afolabi, A.O., Oyeyipo O.O., Ojelabi R.A., \& Amusan L.M. (2018) Construction Professionals Perception of a web based Recruitment system for skilled. Journal of Theoretical and Applied Information Technology 96(10) · May 2018.

5. Seemiller, C., \& Grace, M. (2017). Generation Z: Educating and Engaging the Next Generation of Students. About Campus, 22(3), 21-26. doi:10.1002/abc.21293

6. Business today (2019) Retrieved from; https://www.businesstoday.com.my/2019/01/29/gen-z-malaysians-exp ect-a-digital-workplace-but-still-value-human-interaction/

7. Anand J., \& Devi C.S., (2016), The Impact of E-Recruitment and challenges faced by HR Professionals. International Journal of Applied Research 2016; 2(3): 410-413.

8. Piabuo S. M., Piendiah N. E., Njamnshi N.L, \& Tieguhong P.J. (2017).The impact of ICT on the efficiency of HRM in Cameroonian enterprises: Case of the Mobile telephone industry. Journal of Global Entrepreneurship Research.

9. Mazen J. Al Shobaki, Samy S. Abu Naser, Suliman A. El Talla, Youssef M. Abu Amuna. HRM University Systems and Their Impact on e-HRM. International Journal of Information Technology and Electrical Engineering, ITEE, 2017, 6 (3), pp.5 - 27.

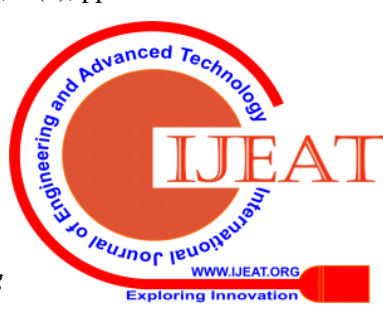


10. Parasuraman, A. (2000). Technology Readiness Index (TRI): A Multiple-Item Scale to Measure Readiness to Embrace New Technologies. Journal of Service Research, 2(4), 307-320.

11. Parasuraman, A., \& Colby, C. (2015). An Updated and Streamlined Technology Readiness Index: TRI 2.0. Journal of Service Research, 18(1), 59-74.

12. Kamble, S., Gunasekaran, A., \& Arha, H. (2018). Understanding the Blockchain technology adoption in supply chains-Indian context. International Journal of Production Research, 1-25. doi:10.1080/00207543.2018.1518610.

13. Loyd, B. H., \& Gressard, C. (1984). Reliability and Factorial Validity of Computer Attitude Scales. Educational and Psychological Measurement, 44(2), 501-505. doi:10.1177/001316448444203.

14. Munger, C.F. and Loyd, B.H. (1989), "Gender and attitudes towards computers and calculators: the relationship to math performance", Journal of Educational Computing Research, Vol. 5 No. 2, pp. 167-77

15. Jayabalan, N., Ramendran, S. P. R., Kadiresan, V., Mohamed R.K.M.H., Apadore K., \& Letchumanan T., (2019). The Perception of University Students on Intention to Use Malaysian Nasional Identity card (My Kad) as a Multipurpose Card. International Journal of Engineering and Advanced Technology (IJEAT) ISSN: 2249 - 8958, Volume-8 Issue-5.

16. Scheier, M. \& Carver, C. (1987). Dispositional Optimism and Physical Well-being: The Influence of Generalized Outcome Expectancies on Health. Journal of Personality, 55(2), 169-210. doi: doi/10.1111/j.1467-6494.1987.tb00434.x

17. Carver, C. S., Scheier, M. F., \& Segerstrom., S. C (2010). Optimism. Clinical Psychology Review 30(7), 879-889. doi: 10.1016/j.cpr.2010.01.006.

18. Hemdi M.A., Rahman S.A.S., Hanafiah M.H., \& Adanan A. (2016) Airport self-service check-in: The influence of technology readiness on customer satisfaction. Taylor \& Francis Group, London

19. Lin, C., Shih, H., \& Sher, P. (2007) .Integrating Technology Readiness into Technology Acceptance: The TRAM Model. Psychology and Marketing, 24(7), 641-657. doi: 10.1002/mar.20177.

20. Flynn, L. and Goldsmith, R. (1993), "A causal model of consumer involvement: replication and critique", Journal of Social Behavior and Personality, Vol. 8 No. 6, pp. 129-42.

21. Dabholkar, P.A. and Bagozzi, R.P. (2002), "An attitudinal model of technology-based self-service: moderating effects of consumer traits and situational factors", Journal of the Academy of Marketing Science, Vol. 30 No. 3, pp. 184-201.

22. Karahanna, E., Straub, D.W. and Chervany, N.L. (1998), "Information technology adoption across time: a cross-sectional comparison of pre-adoption and post-adoption beliefs", MIS Quarterly, Vol. 23 No. 2, pp. 183-213

23. Gefen, D., Karahanna, E., \& Straub, D. W. (2003). Inexperience and Experience with Online Stores: The Importance of TAM and Trust, 50(3), 307-321.

24. Hackbarth G, Grover V, Yi MY. (2003), Computer playfulness and anxiety: positive and negative mediators of the system experience effect on perceived ease of use. Inform \& Management. 40(3), 221-232. doi:10.1016/S0378-7206(02)00006-X.

25. Dabholkar, P.A. (1996), "Consumer evaluations of new technology-based self-service options: an investigation of alternative models of service quality", International Journal of Research in Marketing, Vol. 13 No. 1, pp. 29-51.

26. Norman, K.L. (1997).Teaching in the Switched on Classroom: An Introduction to Electronic Education and Hyper Courseware: http://lap.umd.edu/SOC/ sochome.html, University of Maryland, College Park, MD.

27. Varshney, U. and Vetter, R. (2002) Mobile Commerce: Framework, Applications and Networking Support. Mobile Network and Applications, 7, 185-198. http://dx.doi.org/10.1023/A:1014570512129

28. Walczuch, R., Lemmink, J., \& Streukens, S. (2007). The Effect of Service Employees' Technology Readiness on Technology Acceptance. Journal of Information \& Management, 44(2), 206-215. doi: 10.1016/j.im.2006.12.2005.

29. Lam, S. Y., Chiang, J. W., and Parasuraman, A. (2008). The Effects of the Dimension of Technology Readiness on Technology Acceptance: An Empirical Analysis. Journal of Interactive Marketing, 22(4), 19-39.

30. Kwon H.S., \& Chidambaram, L. (n.d.). A test of the technology acceptance model: the case of cellular telephone adoption. Proceedings of the 33rd Annual Hawaii International Conference on System Sciences. doi:10.1109/hicss.2000.926607.

31. Chen, S. \& Chen, H. (n.d). The Influence of Technology Readiness on the Theory of Planned Behaviour with Self-service Technologies. $\begin{array}{llll}\text { Retrieved } & 15 & \text { July, } & \text { 2018, from }\end{array}$

http://tchinfo.ttu.edu.tw/download/Readiness.pdf?author=hhchen\&id= $11881 \&$ fname $=$ Readiness.pdf.

32. Sekaran, U., \& Bougie, R. (2013). Research Methods for Business: A Skill-Building Approach (6th ed). Chichester, West Sussex: John Wiley \& Sons, Inc.

33. Naoum, S. G. (2013). Dissertation research \& writing for construction students. Abingdon, UK: Routledge.

34. Richardson, S., Balachandher K. Guru., Cheng M. Y., Khong K. W., \& Leo P., (2005), How to research: A guide for undergraduate \& graduate students (pp. 29-37). Kuala Lumpur: Thomson

35. Roscoe, J.T. (1975) Fundamental Research Statistics for the Behavioral Science, International Series in Decision Process, 2nd Edition, Holt, Rinehart and Winston, Inc., New York

36. Krejcie, R. V., \& Morgan, D. W. (1970). Determining Sample Size for Research Activities. Educational and Psychological Measurement, 30(3), 607-610. doi:10.1177/001316447003000308.

37. Hair JF, Ringle CM, Sarstedt M. Partial least squares structural equation modeling: Rigorous applications, better results and higher acceptance. Long range planning. 2013 Mar 14;46(1-2):1-2.

38. Davis, F. D., Bagozzi, R. P., \& Warshaw, P. R. (1989). User acceptance of computer technology: a comparison of two theoretical models. Management science, 35(8), 982-1003. Retrieved from https://www.jstor.org/stable/2632151.

39. Yong AG, Pearce S. A beginner's guide to factor analysis: Focusing on exploratory factor analysis. Tutorials in quantitative methods for psychology. 2013 Oct;9(2):79-94.

40. Fornell C, Johnson MD, Anderson EW, Cha J, Bryant BE. The American customer satisfaction index: nature, purpose, and findings. Journal of marketing. 1996 Oct;60(4):7-18.

41. Fornell C, Larcker DF. Evaluating structural equation models with unobservable variables and measurement error. Journal of marketing research. 1981 Feb;18(1):39-50.

42. Henseler J, Ringle CM, Sarstedt M. A new criterion for assessing discriminant validity in variance-based structural equation modeling. Journal of the academy of marketing science. 2015 Jan 1;43(1):115-35.

43. Kline RB.(2015) Principles and practice of structural equation modeling. Guilford publications; 2015 Nov 3.

44. Gold A.H., Malhotra A., \& Segars A.H. (2001). Knowledge management: An organizational capabilities perspective. Journal of management information systems. 2001 May 31;18(1):185-214.

45. Hair JF, Ringle CM, Sarstedt M. (2011) PLS-SEM: Indeed a silver bullet. Journal of Marketing theory and Practice. 2011 Apr 1;19(2):139-52.

46. Lowry PB, Gaskin J. (2014). Partial least squares (PLS) structural equation modeling (SEM) for building and testing behavioral causal theory: When to choose it and how to use it. IEEE transactions on professional communication. 2014 Apr 22;57(2):123-46.

47. Sarstedt M, Ringle CM, Smith D, Reams R, Hair Jr JF (2014). Partial least squares structural equation modeling (PLS-SEM): A useful tool for family business researchers. Journal of Family Business Strategy. 2014 Mar 1;5(1):105-15.

48. Chin WW. The partial least squares approach to structural equation modeling. Modern methods for business research. 1998 Jan;295(2):295-336.

49. Hair Jr JF, Hult GT, Ringle C, Sarstedt M. (2016). A primer on partial least squares structural equation modeling (PLS-SEM). Sage publications; 2016 Feb 29.

50. Falk RF, Miller NB. (1992). A primer for soft modeling. University of Akron Press; 1992.

51. Hair, J. F., Hult, G. T. M., Ringle, C. M., and Sarstedt, M. (2017). A Primer on Partial Least Squares Structural Equation Modeling (PLS-SEM)., 2nd Ed., Thousand Oakes, CA: Sage.

52. Noh, N., Mustafa, H., \& Ahmad, C. (2014). Predictive Relationship between Technology Acceptance Readiness and the Intention to Use Malaysian Edu web TV among Library and Media Teachers. Procedia - Social and Behavioral Sciences, 116, 144-148.

53. Security Awareness Program Special Interest Group (2014, October). Best Practices for Implementing a Security Awareness. PCI Security Standards Council. Retrieved July 17, from https://www.pcisecuritystandards.org/documents/PCI_DSS_V1.0_Bes t_Practices_for_Implementing_Security_Awareness_Program.pdf

54. Cochran, T. (2013). How to Ensure Your Technology is Secure, Stable and Scalable. Entrepreneur. Retrieved July 17, 2017, from https://www.entrepreneur.com/article/229909. 


\section{AUTHORS PROFILE}

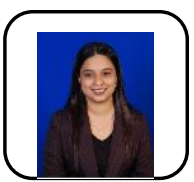

Ms. Neeta Jayabalan is an academician at Faculty of Business, Accounting and Management, SEGi University, Kota Damansara. She has more than 5 years experiences in cooperate and more than 10 years in academia. Her expertise is in the field of Human Resource Management, Business, and Management. She has taught Subjects such as Negotiation and Conflict Management, Entrepreneurship, Organizational Behavior, Business Ethics and various Human Resource Subjects. She is currently active in her research and publication and collaborating research work with other universities. Ms. Neeta holds a Master degree in Human Resource Management and Bachelor degree in Public Management from University Utara Malaysia (UUM) and currently pursuing her PhD studies at University Kebangsaan Malaysia (UKM). She also obtain professional body membership, Malaysian Institute of Human Resource Management (MIHRM) and Malaysia Institute of Management (MIM).

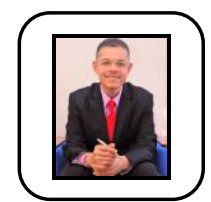

Prof. Dr. Zafir Khan bin Mohamed Makhbul is a Professor at School of Management, Faculty of Economics and Management, University Kebangsaan Malaysia. He has over 20 years of teaching and research experience with Universiti Kebangsaan Malaysia (UKM). He obtained his Bachelor of Business Administration from University Utara Malaysia, Master of Business Administration from University Kebangsaan Malaysia and Ph.D in Management from University Technology Malaysia. He spent over 20 years of researching, writing and lecturing on the theme "Organizational Management and Human Resource Management” in Malaysia. His books have become major and supplement references in Public and Private Higher Learning Institutions and Colleges. His recognitions of expertise/academic and industrial experience have been proven through the appointments as Program External Examiners, Member Board of Studies, Board of Moderators, Academic/ Course Advisor and Technical Committee for National and International Conferences. Amongst his best achievements are National Book Award 2017 for the Category of Best Entrepreneurial Book, Gold Medal Award in IIDEX 2017, Silver Medal Award in IIDEX 2016; Certificate of Appreciation for Outstanding Effort in Writing Organizational Management by McGraw-Hill Education (Asia) 2008.

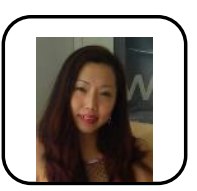

Ms Jenny Marisa Lim Dao Siang is a lecturer of Faculty of Business and Finance, Universiti Tunku Abdul Rahman. She has over 12 years of commercial experiences and more than 10 years of teaching experiences in Marketing field. She is currently active in her research and publications with Universiti Tunku Abdul Rahman and collaborate with other universities in Malaysia. She obtained her Bachelor of Business Administration (Hons) from Abertay Dundee, Scotland, United Kingdom, Master of Business Administration (specialized in Multimedia Marketing) from Multimedia University (Cyberjaya) and she is pursuing her PhD in Hospitality and Tourisms from Universiti Pendidikan Sultan Idris. Her areas of interest in research are Branding Management, Hospitality and Tourism Marketing, Service Marketing, Consumer Behavior and Green Marketing, as well as other multi-discipline research area. Her teaching experiences and recognitions have given her an opportunity to be appointed as MBA and Mphil Examiner from 2018 to current. She is a member of Centre of Business and Management since September 2010. She also participate UTAR Emergency Response Team and continue her efforts to participate as Sponsorship and fund collection for VASI projects. She is currently collaborating with Lambert Academic Publishing for publishing books. Currently, she is also looking forward for some opportunities such as consultation works and grant's projects

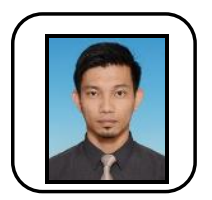

Mr. Nor Azim bin Hj. Ahmad Radzi is a Lecturer at Faculty of Business and Finance, Universiti Tunku Abdul Rahman (UTAR) Kampar Campus and a Member of Centre for Business and Management, UTAR. He obtained his Bachelor of Commerce and Management (Accounting) from Lincoln University New Zealand and Master of Business Administration (Entrepreneurship) from University Malaysia Sabah. Prior to his career as a lecturer, he has been spending time in the auditing and accounting industry mainly as internal auditor and accounting executive. His recognitions of expertise/academic and industrial experience have been proven through the appointments as Head of Cluster (Committee Member) of Department Curriculum Development Committee (DCDC), Academic/ Course Advisor and Course Moderator for subjects such as International Business, Entrepreneurship and Business and Society. Amongst his recent publications are in Elsevier's Telematics and Informatics
Journal, International Journal of Science Arts and Commerce and International Journal of Business, Economics and Law

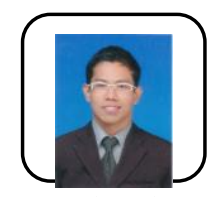

Mr. Muhammad Ashraf Bin Anuar was born in Alor Setar, Kedah in 1989. He received Diploma in Business Management and Bachelor degree in Business Administration (Islamic Banking and Finance) both are from University Islam Antarabangsa Sultan Abdul Halim Muadam Shah in Kedah. He then obtained his Master in Science (Finance) from University Utara Malaysia. Currently, he furthers his Ph.D. In 2015, he joined the Faculty Business and Finance under department of Finance, Universiti Tunku Abdul Rahman in Kampar Perak as a lecturer. His current research interest includes, capital structure, corporate governance, women as a board of directors, and Islamic finance and banking contracts. 